\title{
Does Inward Foreign Direct Investment Promote Export? Empirical Evidence from Sri Lanka
}

\author{
NPG Samantha (Corresponding author) \\ School of Economics, Huazhong University of Science and Technology, P.R. China \\ E-mail: samanthanpg@yahoo.com
}

Liu Haiyun

School of Economics, Huazhong University of Science and Technology, P.R. China

Received: April 27, 2018 Accepted: May 11, 2018 Published: May 31, 2018

doi:10.5296/ber.v8i3.13061 URL: https://doi.org/10.5296/ber.v8i3.13061

\begin{abstract}
Export-led growth hypothesis assumed that long-term economic growth can be achieved through higher exports. Foreign Direct Investment (FDI) is one of the determinants of export performance that can have a substitute effect or complementary relationship to export. The aim of this study is to investigate the impact of inward FDI on the export performance of Sri Lanka during the period from 1980 to 2016. Auto Regressive Distributed Lag (ARDL) model and bound test are applied to identify the long-run relationship and short-run dynamics of the selected variables. The short-run causality is checked by applying the Granger causality test. The ARDL bound test confirms long-run relationship among the variables. The study finds positive insignificant long run and short-run relationships between FDI and exports in Sri Lanka for the data period. Exports are highly sensitive to GDP and real effective exchange rate in the short-run and to domestic investment in the long-run. In order to promote exports via FDI, government policy should focus on attracting more FDI by drawing attention to national competitiveness. The study suggests a comprehensive sector level investigation on the impact of FDI on export performance of Sri Lanka.
\end{abstract}

Keywords: Foreign direct investment, Export, Complementary effect, Substitute effect

\section{Introduction}

Foreign direct investment (FDI) is international capital that flows from one country to another by creating a subsidiary or acquiring control over a business firm in another country. Further, it transfers not only funds to the host country but also advanced technology and 
management skills. It links the domestic economy to the world, creates employment and expands trade. FDI has a direct and indirect effect on a country's productivity that can ultimately help it to achieve economic growth and development (Balasubramanyam et al., 1996; Haruna Danja, 2012; Iamsiraroj and Ulubaşoğlu, 2015; Mijiyawa, 2017; Zilinske, 2010). In this scenario, it is important to examine whether these investments really contribute towards improving the economic indicators of the host country. Thus, this study is an attempt to examine the role played by FDI in boosting the export performance of Sri Lanka.

Examining FDI's effect on exports is important for many reasons. The export-led growth hypothesis postulates that long-term economic growth can be achieved through higher exports (Bashir, Mujahid, and Nasim, 2015; Maneschiold, 2008). Looking at the demand side, persistent growth in demand cannot be expected from a small domestic market. Further, the economic growth that is stimulated by the domestic market demand is subject to fast cessation (Tsen, 2010). In marked contrast, export markets are open to the world, present almost boundless opportunities and promote growth from the demand side. Thus, export can be considered as a vital factor in promoting growth in income as well as being an element of aggregate demand (Gabrielle, 2006; Zestos and Tao, 2002). Furthermore, exporting firms have to increase labor productivity and total factor productivity to compete with foreign firms. Higher exports create well-paid jobs that stimulate productivity by motivating employees. The increase in foreign exchange earnings through export can also be used to import capital goods that are needed to transform the economic structure of developing economies (Herrerias and Orts, 2010; Mijiyawa, 2017). Hence, the expansion of export is an objective of any economy that wishes to achieve economic growth and development.

Considering the positive impact of FDI on a host country's economic growth and development, many developing countries during the 1980s and 1990s reformed their economic policies so as to attract more FDI. As a result, developing countries received an inflow of US \$646 Billion in FDI from developed as well as other developing countries in 2016 (UNCTAD, 2017).

Sri Lanka was under British colonial rule during the period 1815-1948. In post-independent Sri Lanka, contrasting economic policies such as inward-looking and outward-looking were employed by the successive governments that came to power from time to time. The government that was elected in 1977 implemented liberalized economic policies, being the very first country in the South Asian region to do so. The goals of the new economic policy package, which covered all sectors of the economy, were private sector-driven economic growth, export-led growth, and FDI promotion. The establishment of Export Processing Zones, Export Development Board in 1978 and Board of Investment (BOI) were such attempts undertaken by the Sri Lankan government to facilitate and promote exports and FDI.

Soon after the liberalization, Sri Lanka recorded substantial improvement in export earnings as well as FDI. For instance, export as a percentage of GDP increased to 29.2 percent in 1979 from 18.7 percent in 1977. Further, the value of inward FDI increased to US \$47 million in 1979 against US $\$ 1.5$ million in 1978. Export earnings continued to record a substantial improvement during the 1980s and 1990s. The average annual growth of export earnings in 
the 1980s and 1990s was 7.4 percent and 11.06 percent, respectively. However, in the 2000s, average annual export earnings increased by only 5.11 percent, recording lower performance compared to the previous two decades. The trade deficit has been widening significantly since 2011 due to an increase in import expenditure over export earnings. The trade deficit was US $\$ 9,090$ million in 2016 because the import expenditure was nearly double that of export earnings. Sri Lanka is under immense external pressure at present due to the high current account deficit and heavy foreign debt servicing (CBSL, 2016).

Sri Lanka is a unique example from the South Asian region, as it scores better on the social indicators such as adult literacy, life expectancy at birth and social security. The opportunity of attracting industry oriented FDI is high with its skilled and trainable labor force. The relationship between FDI and aggregate export may vary from country to country based on country-specific characteristics. It has been more than four decades since the Sri Lankan economy was liberalized by removing trade-related barriers and tax incentives offered to foreign investors to attract FDI and promote exports. It is not certain whether FDI stimulates exports and correlate the two variables in Sri Lanka. Hence, the objective of this study is to investigate empirically the relationship between inward FDI and export performance of Sri Lanka at the aggregate level for the period 1980-2016. The findings of the study will provide a direction to government officials and policymakers on how to manage macroeconomic variables and economic policies in order to promote exports through FDI. Further, the findings could be used as an example for other developing countries with similar economic characteristics as Sri Lanka.

As for the rest of the paper, in section two, theoretical relationship between FDI and export as well as the results of the latest empirical study are discussed. The empirical model and analysis tools are discussed in section three and the results are presented in section four. Section five concludes the study with policy recommendations.

\section{Literature Review}

\subsection{Theoretical Link between Inward FDI and Exports}

The impact of FDI on export performance has long been discussed in the economic literature. Neoclassical trade theory of Heckscher-Ohlin-Samuelson (HOS) (Samuelson, 1953) was of the view that differences in factor endowment and factor prices of the homogeneous product in different countries provided the foundation for international trade. If factors move across countries, the difference would be smaller. Based on the HOS assumptions, Mundell (1957) asserted that FDI reduces export because it moves capital from one country to another, sinking differences in factor endowment and factor prices. By considering country-level differences in the production function, Purvis (1972) emphasized that international trade can be expanded by FDI as it presents more opportunities for importing and exporting different products. Kojima (1975) showed that both Mundell (1957) and Purvis (1972) had failed to show identical conditions for complement or substitute case of FDI to trade. FDI is a package that comprises foreign capital, technology, managerial skills and a global network. FDI increases productivity and operating efficiency at firm level as well as at industry level. The transfer of advanced technology and managerial skills from foreign firms to local firms 
would enhance the competitive position of host country firms in the foreign market. Kojima concluded that FDI would be complementary to commodity trade only when investing in industries in which host country has a comparative advantage.

There may be direct and indirect effects of FDI on host country exports. The direct effect depends on the production characteristics of the investing industry. First, foreign firms may have better technological, management and marketing skills in processing raw materials than local firms. Such an investment may have a direct effect on the export performance of host country. MNEs bring advanced technology, management skills and global network linkages to the host country and will link the host country to the world more efficiently than export-oriented local firms. Second, indigenous exporters have to face several obstacles in the process of becoming a successful exporter. Labor-intensive finished product exporting firms have to find a global market in order to expand export, establish distribution network, learn about industrial norms and safety standards and achieve competitiveness. In such an environment, MNEs can play an intermediary role, connecting indigenous firms to the global market. Third, labor-intensive vertically integrated export expands with the intervention of MNEs. MNEs may ship semi-finished and unfinished goods to the host country for further processing or assembly and re-export finished goods to their home country or target markets. Such operations by MNEs can diversify the host country's export bundle (Rahmaddi and Ichihashi, 2013; Zhang and Markusen, 1999). There may be several indirect effects of FDI on export performance. Domestic export-oriented firms can learn much by observing the MNEs export activities so that the indigenous firms can expand export by discovering new markets and improving their existing infrastructure and financial services (Haddad and Harrison, 1993). Improvement of competitiveness and technological diffusion are also another indirect effect of FDI on export performance. At the time of entry, MNEs are usually more productive than local firms. Therefore, local firms will have to change their production processes by adopting technology that is more advanced. Only productive local exporters can survive in the export market in the presence of MNEs (Rahmaddi and Ichihashi, 2013).

However, FDI may reduce the volume of exports by replacing domestic savings and investment, transferring inappropriate technology in relation to factor proportion of host country and by targeting the domestic market. Furthermore, FDI could have an impact on the expansion of indigenous firms by reducing their competitiveness. By focusing mainly on the supply of cheap local labor, FDI might reduce the country's dynamic comparative advantage (Zhang, 2005).

\subsection{Empirical Evidence}

The impact of FDI on export performance has been examined by many empirical studies. Though economic theory propounds that a positive relationship exists between FDI and exports in developing countries, empirical studies have not been able to show conclusive results. In country-level aggregate studies, Akoto (2016) examined the causal relationship between FDI, exports, and GDP using South African quarterly data from 1960 to 2009. The findings revealed a positive and significant relationship between FDI and exports for the data period. However, South African exports were not very responsive to changes in FDI due to 
the nature of inward FDI, which targeted mostly local markets through mergers and acquisitions. Shamim et al. (2016) analyzed the relationship between FDI and the aggregate exports of Pakistan for the period 1976 to 2012. The study found a positive long run and short-run relationship between the two variables, confirming the complementary relationship. In contrast, Temiz and Gökmen (2011) empirically analyzed the relationship between FDI and exports on VAR framework using Turkey's data from 1991 to 2010. They could not find any significant positive spillover from FDI to exports. Guru-Gharana and Adhikari (2011) found a unidirectional causality from export towards FDI under the Toda-Yamamoto framework for China. The result suggested that domestic consumption and import substitution oriented FDI may limit the export performance. Accordingly, the effect of FDI on export performance may vary according to country-specific characteristics and the nature of FDI.

Most recent cross-country studies have found that the relationship between FDI and export performance may vary according to the region, country, as well as industry. Analyzing data of 12 Central and Eastern European countries, Kutan and Vuksic (2007) separated the impact of FDI on export performance into supply capacity and FDI-specific effects. FDI had a significant impact on increasing supply capacity leading to more exports in all the selected countries. However, positive FDI effect on export depends on the amount of FDI that accumulates over time. Ahmed et al. (2011) found the direct and indirect effects of FDI on economic growth through export in African economies. Karsalari et al. (2013) employed panel integration and co-integration techniques to analyze the relationship between FDI and export for 40 Asian countries for the period 1970 to 2010. The study found a significant positive relationship between the two variables. The impact of FDI on export can be modified by other factors such as the cost of doing business, quality of infrastructure and level of corruption. Amighini and Sanfilippo (2014) added to the literature by analyzing the impact of external funds on the export performance of African countries. Further, the study had distinguished between external flows originating from developing countries and developed countries. The study found a positive relationship between export and FDI from both South-South and North-South external flows. The South-South relationship is more likely to affect export diversification than North-South due to the fact that a smaller technological gap, diversified investment, and more adaptable technologies tend to prevail in the former. Hence, that study has recommended attracting more investments from developing countries in order to diversify the export basket of Africa. Clus-Rossouw et al. (2015) investigated the impact of BRICS FDI on South African Developing Country's (SADC) exports from panel data collected from 2003 to 2011. FDI had a significant impact on the supply capacity of the host country, thus boosting the host country's exports significantly. Mijiyawa (2017) examined the impact of FDI on export performance of 53 African countries using panel data from 1970 to 2009. The result confirmed a positive relationship between two variables, FDI and exports. The effect of FDI on exports diminished when controlled for gross capital formation.

Industry and sector level studies have found a significant impact of FDI on export performance in host countries based on country-specific characteristics. Rahmaddi and Ichihashi (2013) reviewed the impact of FDI on industry based manufactured exports of 
Indonesia using panel data from 1990 to 2008. The findings confirmed the argument that the level of FDI increases the performance of exports, especially of those from the manufacturing sector. The effect of FDI in the manufacturing sector varies according to the factor intensity and technological capacity. FDI has changed the Indonesian export composition from raw materials and low technology goods to technically complex, high-value products. Davaakhuu et al. (2015) examined the determinants of export using panel data from Mongolia in respect of its mining, manufacturing and primary sectors for the period from 1995 to 2012; FDI was found to act as a powerful driving force in expanding exports.

By reviewing the most recent empirical literature on the effect of FDI on export performance of the host country, it can be concluded that the effect of FDI on export performance depends on country-specific characteristics and varies over time. This study will, therefore, focus on investigating the impact of FDI on the export performance of Sri Lanka by using the latest econometric techniques.

\section{Empirical Framework and Methodology}

\subsection{Model Specification}

Export performance depends on foreign demand and domestic supply. Export demand is a function of world income, relative price, and the effective exchange rate. Conventional trade theory postulates a negative relationship between relative price and export demand. If exports are relatively low-priced, export demand would be high. World income determines the ability to purchase; hence, a positive relationship exists between world income and exports. Depreciation of host country's real effective exchange rate would boost export demand through increased competitiveness (Davaakhuu et al., 2015).

Based on trade theory, we can expect improvement in export supply when export prices are higher than domestic prices. FDI is a divisive factor for export supply. One argument is that FDI would increase exports because it brings in capital and superior technology. There are others who argue that export supply depends on the motive behind FDI. If FDI is motivated by tax and non-tax incentives and to bypass trade barriers, such FDI would not promote exports. However, FDI motivated by the country's strategic advantages such as location, low labor costs, raw material supplies etc. would tend to increase the export volume. Hence, it is necessary to conduct an empirical investigation on the impact of FDI on export performance (Davaakhuu et al., 2015). If the quality of domestic infrastructure is good that would reduce export costs and ensure timely supply. Hence, improvement in infrastructure is positively correlated with export supply. Further, trade liberalization contributes towards increasing export supply by reducing anti-export bias. Then, we can summarize the determinants of export considering both demand and supply factors.

$$
E X P=f(W Y, D C, F D I, I N F, L I B, R E E R, R P)
$$

Where, EXP $=$ export, WY $=$ World income, $\mathrm{DC}=$ Domestic capital formation, FDI $=$ Foreign direct investment, INF = Infrastructure, LIB $=$ Trade liberalization, REER $=$ Real effective exchange rate, and $\mathrm{RP}=$ Relative price 
Accordingly, export performance depends not only on FDI but also on several other factors. In order to capture the impact of FDI on the export performance of Sri Lanka at the aggregate level, the model is based on a simplified form of the export equation as used by Rose (1990), Jongwanich (2010), and Rahmaddi and Ichihashi (2013). FDI can have an effect on export from the supply side directly or indirectly through improving productive capacity or export spillover, respectively (Markusen and Venables, 1989). In line with Zhang and Song (2001), Sun (2001), and Rahmaddi and Ichihashi (2013), this study uses real GDP, gross fixed capital formation and real effective exchange rate along with FDI to capture the export performance. The theoretical relationship between export and other explanatory variables can be given as follows:

$$
\operatorname{Exp}=f(F D I, D I, G D P, R E E R)
$$

The econometric model of equation (2) can be written as,

$$
\operatorname{Exp}_{t}=\alpha_{0}+\alpha_{1} F D I_{t}+\alpha_{2} D I_{t}+\alpha_{3} G D P_{t}+\alpha_{4} R E E R_{t}+\mu_{t}
$$

Using equation (3), we can write the ARDL econometric model for the analysis as follows:

$$
\begin{gathered}
\Delta \operatorname{Exp}_{t}=\alpha_{0}+\alpha_{1} \operatorname{Exp}_{t-1}+\alpha_{2} F D I_{t-1}+\alpha_{3} D I_{t-1}+\alpha_{4} G D P_{t-1}+\alpha_{5} R E E R_{t-1}+ \\
\sum_{t-1}^{t-n} \beta_{0} \Delta \operatorname{Exp}_{t-1}+\sum_{t-1}^{t-n} \beta_{1} \Delta F D I_{t-1}+\sum_{t-1}^{t-n} \beta_{2} \Delta D I_{t-1}+\sum_{t-1}^{t-n} \beta_{3} \Delta G D P_{t-1}+\sum_{t-1}^{t-n} \beta_{4} \Delta R E E R_{t-1}+\mu_{t}
\end{gathered}
$$

Where, $\alpha_{0}$ is the intercept, $\mu_{t}$ is the error term, $\alpha_{1}$ to $\alpha_{5}$ represent the long-run elasticity, and $\beta_{0}$ to $\beta_{4}$ are the short-run dynamic of independent variables. FDI is the inward foreign direct investment to Sri Lanka over the corresponding period, DI is the domestic investment, GDP is the gross domestic product, and REER is the index value of the real effective exchange rate weighted to major trading partners of Sri Lanka.

The objective of the analysis is to identify the impact of FDI on export performance; hence, the volume of annual exports is used as the dependent variable. The expected sign of the coefficient of FDI $\left(\alpha_{2}\right)$ would be positive or negative depending on whether FDI substitutes or complements the export on Sri Lankan data. In addition to FDI, three more variables that can affect the export performance are included. The objective of adding domestic investment is to keep constant the effect of domestic investment on export performance. The expected sign of $\alpha_{3}$ is positive because an increase of domestic investment will increase the productive capacity enabling producers to expand production. The importance of domestic investment on export performance has been highlighted by some previous studies (Rahmaddi and Ichihashi, 2013; Sun, 2001; Zhang and Song, 2001). Economic performance of a country increases the supply capacity for export. Because GDP is an indicator of economic performance, real GDP is incorporated as a variable in the model to capture the level of that performance. In national account calculations, exports are considered a part of GDP. Thus, in order to overcome the problem of accounting identity, non-export GDP is used as done by Akoto (2016). A positive coefficient is expected for GDP with export $\left(\alpha_{4}\right)$. Real effective exchange rate is also another important trade related variable, which represents competitiveness in the export market. This study uses the index value of REER, which is calculated based on the consumer price index and weighted currency value of 24 major 
trading partners of Sri Lanka. Lower index values indicate higher competitiveness of the country in the world market. Hence, a negative coefficient $\left(\alpha_{5}\right)$ of REER is expected with export performance.

\subsection{Data Description and Sources}

Sri Lanka liberalized her economy in 1978 with the objective of attaining rapid economic growth through external sector development. This study is based on annual time series data from 1980 to 2016 to capture the progress of the major economic reforms. The required data for the selected variables were mainly collected from the Central Bank of Sri Lanka (CBSL). In addition, World Development Indicators (WDI) and United Nations Conference on Trade and Development (UNCTAD) databases were used to verify the reliability of the data and to fill the data gaps. All the variables except REER were converted into real values by using DGP deflator $(1996=100)$ published by the CBSL.

\section{Estimation and Results}

\subsection{Unit Root Test}

The objective of conducting a unit root test is to check whether the variables under consideration are stationary or not. If the mean and variance of the time series are infinite and independent of time, such variables are said to be stationary. Time series data have a unit root problem if the mean and variance of variables change over time.

Verification of the order of integration of all the variables by conducting a unit root test is a prerequisite for co-integration analysis. In order to apply conventional co-integration techniques, all the variables should be integrated at the same level. However, the technique known as Auto-Regressive Distributed Lag (ARDL) introduced by Pesaran et al. (2001) overcomes this issue and can be applied to the variables integrated at $\mathrm{I}(0)$ and $\mathrm{I}(1)$. Furthermore, none of the variables should be stationary at I(2) when applying this technique. Hence, in order to examine the level of integration of the variable under consideration in this model, the extensively used Augmented Dickey-Fuller (ADF) unit root test is applied.

ADF unit root test results are presented in Table 1. According to this, only one variable is stationary at level I(0). Hence, by taking the first difference, all the variables are again tested on the null hypothesis of the unit root. At the first difference, all the variables became stationary at $1 \%$ level, accepting the alternative hypothesis. Since variables are stationary at different levels $\mathrm{I}(0)$ and $\mathrm{I}(1)$, it is rationalized by applying the ARDL co-integration model developed by Pesaran et al. (2001) for the selected model. Furthermore, compared to Engle and Granger (1987), and Johansen and Juselius (1990) co-integration techniques, the ARDL model is more appropriate for use with small and finite sample sizes; it provides unbiased long-run estimates and can be applied with variables integrated on $\mathrm{I}(0)$ and $\mathrm{I}(1)$ (Belloumi, 2014). 
Table 1. ADF unit root test results

\begin{tabular}{|c|c|c|c|}
\hline \multirow[t]{2}{*}{ Variables } & \multirow[t]{2}{*}{ Status } & \multicolumn{2}{|c|}{ ADF test statistics } \\
\hline & & Intercept & Trend and intercept \\
\hline $\log \operatorname{Exp}$ & At levels & $-2.1195(0.2385)$ & $-3.1454 \quad(0.1116)$ \\
\hline $\log \mathrm{FDI}$ & At levels & $-4.0628 *(0.0033)$ & $-4.8854 *(0.0020)$ \\
\hline $\log \mathrm{DI}$ & At le & $1.7223 \quad(0.9995)$ & $-2.4415 \quad(0.3678)$ \\
\hline $\log G D P$ & s & $-0.9691 \quad(0.7537)$ & $-0.7182 \quad(0.9639)$ \\
\hline logREER & At le & $-0.8464 \quad(0.7934)$ & $-2.0947 \quad(0.5312)$ \\
\hline$\Delta \log \operatorname{Exp}$ & $1^{\text {st }}$ difference & $-6.5053 *(0.0000)$ & $-6.3635^{*}(0.0000)$ \\
\hline$\Delta \log F D I$ & $1^{\text {st }}$ difference & $-5.1329 *(0.0002)$ & $-5.1745^{*}(0.0011)$ \\
\hline$\Delta \log \mathrm{DI}$ & $1^{\text {st }}$ difference & $-7.8924 *(0.0000)$ & $-8.7528 *(0.0000)$ \\
\hline$\Delta \log G D P$ & $1^{\text {st }}$ difference & $-4.7603 *(0.0005)$ & $-5.2635 *(0.0003)$ \\
\hline$\triangle \operatorname{logREER}$ & $1^{\text {st }}$ difference & $-6.4014 *(0.0000)$ & $-5.0114 *(0.0023)$ \\
\hline
\end{tabular}

Notes: $\mathrm{P}$ values are in parentheses, $\Delta$ indicates the first difference, ${ }^{*}$ significant at $1 \%$ level Source: Own study

\subsection{ARDL Regression Analysis}

The estimated results of equation 4 using the ARDL model developed by (Pesaran et al. 2001) are presented in Table 2. The lag length is selected automatically using Akaike Information Criterion (AIC) for the ARDL model with a maximum lag of four. The selected lag lengths of the model are 3,0,0,1,4 for the selected variables. The probability value of F-statistic is highly significant indicating the overall performance of the selected model. Further, the Durbin-Watson value is higher than the R-squared value, rejecting the chance of spurious results, serial correlation, and autocorrelation. The goodness of fit of the selected model is at the desired level; more than $90 \%$ of the variance of the dependent variable can be explained by independent variables.

The positive sign of the coefficient value of FDI confirms a complementary relationship between exports and FDI. In other words, FDI can have a positive effect on Sri Lankan export performance at the aggregate level. However, the contribution of FDI to export performance at the aggregate level is not statistically significant. This has to be taken into consideration when formulating FDI related policies focusing on export performance. The coefficients of GDP and real effective exchange rate (REER) were significant at the 5\% level with the expected sign. Furthermore, the coefficient of domestic investment also produced the expected sign and was significant at the $10 \%$ level.

The existence of a long-run relationship and long-run coefficient of the selected variables are estimated by applying the ARDL long form and bound test. The long-run relationship between the dependent variable and the independent variable is indicated by a long-run coefficient. Estimated results of the long-run coefficient are presented in Table 3. FDI, GDP, and domestic investment are positively correlated with exports while the real effective exchange rate is negatively correlated in the long-run. However, the study failed to find a strong long-run relationship between FDI and exports in the Sri Lankan context. A strong 
positive long-run relationship can be found between domestic investment and exports.

Table 2. Regression results of ARDL model

\begin{tabular}{|l|l|l|l|}
\hline Variables & Coefficient & t-statistics & Probability value \\
\hline $\log E x p(-1)$ & 0.3643 & 2.5236 & 0.0202 \\
\hline $\log \operatorname{Exp}(-2)$ & -0.1290 & -0.7744 & 0.4477 \\
\hline $\operatorname{logExp}(-3)$ & 0.4928 & 3.2144 & 0.0044 \\
\hline $\operatorname{logFDI}$ & 0.0544 & 1.6774 & 0.1091 \\
\hline $\log \mathrm{GDP}$ & 0.3606 & 3.5479 & 0.0020 \\
\hline $\operatorname{logDI}$ & 0.5053 & 1.9915 & 0.0603 \\
\hline $\operatorname{logDI}(-1)$ & -0.4932 & -1.7683 & 0.0922 \\
\hline $\operatorname{logREER}$ & -0.7411 & -2.6430 & 0.0156 \\
\hline $\operatorname{logREER}(-1)$ & -0.4818 & -1.7114 & 0.1025 \\
\hline $\operatorname{logREER}(-2)$ & 0.4432 & 1.6658 & 0.1113 \\
\hline $\operatorname{logREER}(-3)$ & 0.2093 & 0.7959 & 0.4354 \\
\hline $\operatorname{logREER}(-4)$ & -0.6243 & -2.6105 & 0.0167 \\
\hline Constant & 3.9800 & 2.0582 & 0.0528 \\
\hline
\end{tabular}

$\begin{array}{ll}\text { R-Squared } & 0.9177 \\ \text { Ad. R-Squared } & 0.8684 \\ \text { Durbin-Watson Stat } & 1.8098 \\ \text { F-statistic } & 18.6079 \\ \text { Pro (F-statistic) } & 0.00000\end{array}$

Source: Own study

The ARDL bound test can be applied to verify the presence of a long-run relationship between a dependent variable and independent variables. The bound test assumes null hypothesis of no long-run relation $\left(\beta_{1}=\beta_{2}=\beta_{3}=\beta_{4}=0\right)$ against the alternative hypothesis of long-run relation $\left(\beta_{1} \neq 0, \beta_{2} \neq 0, \beta_{3} \neq 0, \beta_{4} \neq 0\right)$ among the variables of the selected model. The alternative hypothesis is accepted if the F-statistic value of the bound test is greater than the upper critical value given in the Pesaran table. The bound test results presented in Table 4 confirm the presence of a long-run relationship among the variables under consideration.

Table 3. Estimation of the long-run coefficient

\begin{tabular}{|l|l|l|l|}
\hline Variables & Coefficients & t-statistic & Probability \\
\hline $\log$ FDI & 0.2000 & 1.2253 & 0.2347 \\
\hline $\log$ GDP & 1.326 & 1.6284 & 0.1191 \\
\hline $\log$ I & 0.1443 & 3.1452 & 0.0024 \\
\hline $\operatorname{logREER}$ & -4.3967 & -1.7873 & 0.0891 \\
\hline Constant & 14.6361 & 5.2053 & 0.0000 \\
\hline
\end{tabular}

Source: Own study 


\section{Macrothink}

Table 4. Results of ARDL bound test

\begin{tabular}{|l|l|l|l|}
\hline \multicolumn{2}{|l|}{ Bound test value } & \multicolumn{2}{l|}{ Bound critical value } \\
\hline Test statistics & Value & $\mathrm{I}(0)$ & $\mathrm{I}(1)$ \\
\hline F-statistic & 5.3105 & $3.29(1 \%)$ & $4.37(1 \%)$ \\
\cline { 3 - 4 } & & $2.56(5 \%)$ & $3.49(5 \%)$ \\
\cline { 3 - 4 } & & $2.20(10 \%)$ & $3.09(10 \%)$ \\
\hline
\end{tabular}

Source: Own study

\subsection{Error Correction Model}

Error correction model introduced by Engle and Granger (1987) can be used to identify causal factors that can be influenced by the modeled variables. The error correction version of the ARDL model is given by Equation 5.

$$
\begin{gathered}
\Delta \operatorname{Exp}_{t}=\beta_{0} \sum_{t-1}^{t-n} \beta_{1} \Delta E x p_{t-1}+\sum_{t-1}^{t-n} \beta_{2} \Delta F D I_{t-1}+\sum_{t-1}^{t-n} \beta_{3} \Delta D I_{t-1}+\sum_{t-1}^{t-n} \beta_{4} \Delta G D P_{t-1}+ \\
\sum_{t-1}^{t-n} \beta_{5} \Delta R E E R_{t-1}+\lambda E c_{t-1}+\mu_{t}
\end{gathered}
$$

In Equation 5, Ec and $\lambda$ are the error correction term and speed of adjustment parameter respectively. A statistically significant error term with a negative sign is an indication of long-run relationship, which can be obtained from the variable included in the model. Furthermore, the negative sign indicates the convergence of short-run shocks to yield long-run equilibrium. The results of the error correction model of the ARDL are presented in Table 5. The coefficient of the error term is negative and significant at $1 \%$ level indicating convergence towards equilibrium. This indicates the presence of long-run co-integration among the variables. The value of the speed of adjustment parameter is 0.27 meaning that 27 percent of adjustments can be completed within the first period. The value of $\mathrm{R}^{2}$ and adjusted $\mathrm{R}^{2}$ of ECM indicate goodness of fit of the model. Further, the Durbin-Watson stat result confirms the lack of autocorrelation between the variables.

Table 5. ECM regression results

\begin{tabular}{|l|l|l|l|}
\hline Variables & Coefficient & t-statistic & Probability value \\
\hline$\Delta \log \operatorname{Exp}(-1)$ & -0.3637 & -3.3213 & 0.0034 \\
\hline$\Delta \log \operatorname{Exp}(-2)$ & -0.4927 & -4.3947 & 0.0003 \\
\hline$\Delta \log \mathrm{DI}$ & 0.5052 & 2.9830 & 0.0074 \\
\hline$\Delta \operatorname{logREER}$ & -0.7411 & -3.6980 & 0.0014 \\
\hline$\Delta \operatorname{logREER}(-1)$ & -0.0279 & -0.1379 & 0.8916 \\
\hline$\Delta \operatorname{logREER}(-2)$ & 0.4150 & 2.1419 & 0.0447 \\
\hline$\Delta \operatorname{logREER}(-3)$ & 0.6242 & 3.2693 & 0.0038 \\
\hline Ec(-1) & -0.2719 & -6.3115 & 0.0000 \\
\hline R-squared & 0.73 & & \\
Ad. R-squared & 0.65 & & \\
Durbin-Watson stat & 1.809
\end{tabular}

Source: Own study 


\subsection{Diagnostic and Stability Test}

Breusch-Godfrey serial correlation LM test and Breusch-Pagon-Godfrey heteroscedasticity test are applied for residual diagnostics. The results are presented in Tables 6 and 7, respectively. These results indicate that the model is free from serial correlation, homoscedasticity, and heteroscedasticity. The error term is normally distributed and variance is constant in selected variables.

Table 6. Serial correlation LM test (Breusch-Godfrey)

\begin{tabular}{|l|l|l|l|}
\hline Test statistics & Value & Test statistics & Value \\
\hline F-statistic & 0.4345 & Prob F $(2,18)$ & 0.6542 \\
\hline Obs. R-squared & 1.5200 & Prob Chi-square & 0.4676 \\
\hline
\end{tabular}

Source: Own study

In order to check the stability of the selected model, CUSUM and CUSUMSQ tests are used and the results are presented in Figure 1. These tests give results on parameter consistency based on the cumulative sum of recursive residuals and the cumulative sum of squares recursive residuals. The figure plots show the 5\% critical bounds and CUSUM and CUSUMSQ lines. If the CUSUM and CUSUMSQ lines cross the critical bounds, it is an indication of the instability of the regression parameter. The model used in this study is stable because none of the lines cross the critical bounds. Hence, the results validate the use of the model in policymaking. The results of Ramsey RESET also confirm the stability of the model; these results are presented in Table 8.

Table 7. Heteroscedasticity test (Breusch-Pagon-Godfrey)

\begin{tabular}{|l|l|l|l|}
\hline Test statistics & Value & Test statistics & Value \\
\hline F-statistic & 1.4024 & Prob.F (12,20) & 0.2433 \\
\hline Obs. R-squared & 15.0795 & Prob.chi-squared (12) & 0.2371 \\
\hline Scaled explained SS & 5.9101 & Prob.chi-squared (12) & 0.9205 \\
\hline
\end{tabular}

Source: Own study
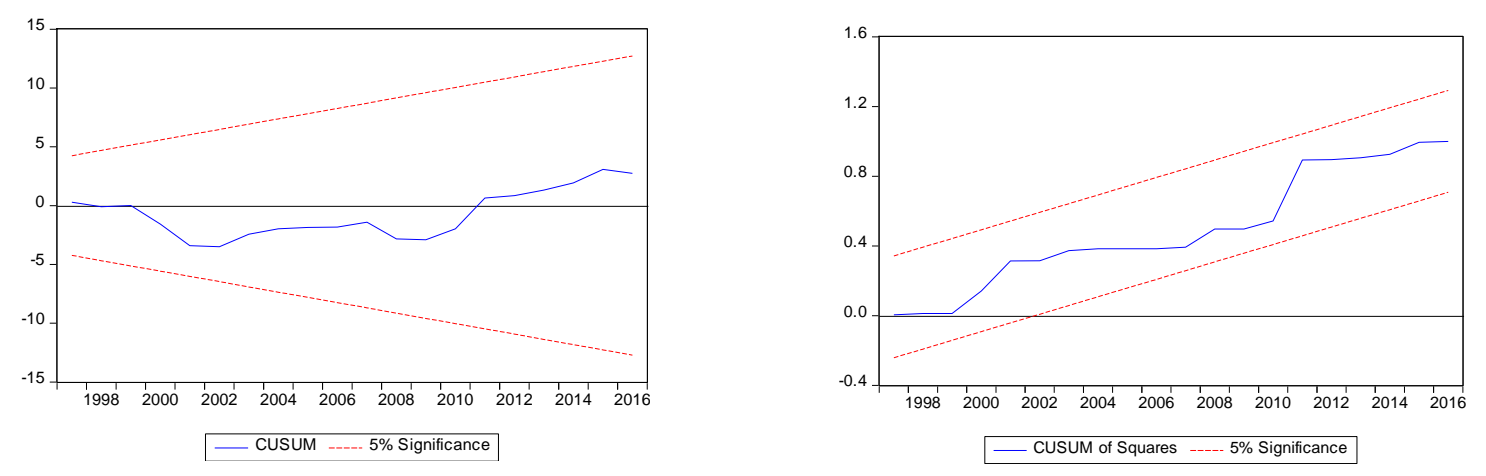

Figure 1. CUSUM and CUSUMSQ tests 
Table 8. Ramsey RESET test

\begin{tabular}{|l|l|l|}
\hline Test statistics & Value & Probability \\
\hline t-statistic & $0.2547(19)$ & 0.8016 \\
\hline F-statistic & $0.0649(1,19)$ & 0.8016 \\
\hline
\end{tabular}

Source: Own study

\subsection{Causality Test}

Granger causality test is used to identify the direction of causality between the selected variables. The results of the short-run causality test are presented in Table 9. Accordingly, unidirectional causality is found from domestic investment and real effective exchange rate to export. Further, the result confirms unidirectional causality from export to GDP. However, the study failed to find any causality running from FDI to selected variables.

Table 9. Results of Granger Causality test

\begin{tabular}{|l|l|l|l|l|l|l|}
\hline Variables & Exp & FDI & GDP & DI & REER & Direction of causality \\
\hline Exp & - & 0.5940 & $9.3528^{*}$ & 2.0689 & 2.3079 & Exp $\rightarrow$ GDP \\
\hline FDI & 2.2351 & - & 1.3668 & 1.5821 & 1.9384 & No causality \\
\hline GDP & 0.5693 & 0.0145 & - & 0.9809 & 0.0392 & No causality \\
\hline DI & $10.1071^{*}$ & 2.5691 & $6.5103 * *$ & - & $11.3000^{*}$ & $\begin{array}{l}\text { DI } \rightarrow \text { Exp, DI } \rightarrow \text { GDP, } \\
\text { DI } \rightarrow \text { REER }\end{array}$ \\
\hline REER & $8.4692^{*}$ & 0.2384 & $4.6584 * *$ & 0,8436 & - & REER $\rightarrow$ Exo, REER $\rightarrow$ GDP \\
\hline
\end{tabular}

Note: $(*)$ and $(* *)$ indicate rejection of no causality at $1 \%$ and $5 \%$ significance level, respectively

Source: Own study

\subsection{Discussion}

The empirical results confirm a positive relationship between FDI and exports of Sri Lanka in the long-run as well as the short-run. Thus, there is a complementary relationship between two variables. In other words, inward FDI is found to be an influential factor on the export performance of Sri Lanka. However, the study fails to find a significant relationship between FDI and exports in the Sri Lankan context in the short-run as well as in the long-run. Most of the empirical studies have found a positive significant relationship between FDI and exports in both developed as well as developing countries. In contrast, some studies have found a positive insignificant relationship between FDI and exports, especially among developing countries. For instance, Pfaffermayr (1994) found an insignificant positive relationship between FDI and export in Austria. Furthermore, Tabassum et al. (2012) found an insignificant positive relationship between the two variables for Pakistan. Hence, the findings of this study are in line with the studies that found an insignificant positive relationship between FDI and export. The impact of FDI on export performance depends on the volume of inward FDI (Kutan and Vuksic, 2007), the motive behind the FDI, and country-specific characteristics (Akoto, 2016). The volume of inward FDI in Sri Lanka is not at a satisfactory 


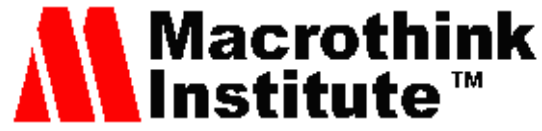

Business and Economic Research ISSN 2162-4860 2018, Vol. 8, No. 3

level. Further, more than 70 percent of the inward FDI in Sri Lanka targets infrastructure building and services such as housing, property development, and the telephone and telecommunication network (Table 10).

Manufacturing sector oriented FDI that can contribute more to export performance was narrowly concentrated on a few labor-intensive low-tech industries such as textiles, apparel, and leather. After the trade liberalization, Sri Lanka's export composition changed from primarily agricultural products to more value-added labor-intensive industrial products. However, the Sri Lankan export basket narrowly concentrated on two traditional products, tea, and garments, which accounted for more than half the export earnings. The export direction of Sri Lanka is also suffering from lack of market diversification as only a few markets are catered to, such as the USA and Europe, which accounted for nearly two-thirds of the total export earnings (CBSL, 2016). Although the study found an insignificant long-run relationship between export and FDI, the contribution of FDI towards diversifying the export basket of Sri Lanka cannot be ignored. During the early stage of liberalization, the inward FDI was strongly oriented towards the traditional labor-intensive garment industry. Later on during the 1990s, an increasing number of foreign firms began producing other labor-intensive products such as footwear, travel goods, and plastic products (Athukorala and Jayasuriya, 2004). Whether there was a spillover effect from foreign firms to local firms in promoting exports in the Sri Lankan context is questionable though. The internal conflict, from which Sri Lanka suffered for nearly three-decades, increased the political risk and uncertainty, and macroeconomic instability. Vertically integrated assembly industries are more sensitive to political risks than those producing light consumer goods. Hence, the country missed the opportunity for attracting vertically integrated assembly industries that could have contributed much to export performance (Athukorala and Jayasuriya, 2004).

Table 10. The composition of inward FDI (percentage of total)

\begin{tabular}{|l|l|l|l|}
\hline Sectors & 2014 & 2015 & 2016 \\
\hline Manufacturing FDI & 20.66 & 26.50 & 30.93 \\
\hline - Textiles, Wearing Apparel, and Leather & 5.14 & 4.68 & 6.17 \\
\hline - Rubber \& Plastics, Petroleum, Chemicals \& Coal & 5.69 & 7.78 & 12.43 \\
\hline Agriculture FDI & 0.35 & 0.40 & 0.24 \\
\hline Infrastructure \& Services FDI & 73.55 & 73.10 & 68.84 \\
\hline Infrastructure & 42.22 & 46.76 & 42.38 \\
\hline$\quad$ - Property Development and Housing & 20.99 & 21.87 & 9.92 \\
\hline - Telecommunication Network and Telephone & 9.43 & 14.32 & 30.41 \\
\hline Services & 31.33 & 26.34 & 26.45 \\
\hline$\quad$ - Hotels \& Restaurants & 4.23 & 18.76 & 17.64 \\
\hline Total FDI (US\$ Million) & $\mathbf{1 6 1 6 . 3 3}$ & $\mathbf{9 6 9 . 6 6}$ & $\mathbf{8 0 1 . 0 0}$ \\
\hline
\end{tabular}

Source: Board of Investment (BOI) - Sri Lanka

The short-run Granger causality test confirms unidirectional causality from domestic investment and real effective exchange rate to exports. The real effective exchange rate 
represents the country's competitiveness in the world market. This indicates the need for macroeconomic stability of the economy for better export performance in the world market.

\section{Conclusion and Recommendation}

Promoting exports is one of the ways in which FDI can influence the economic growth of developing countries. The objective of this study is to identify the long-run relationship between FDI and export performance of Sri Lanka over the period from 1980 to 2016. The ADF unit root test which is applied to identify stationary properties of the selected variables confirms integration of data on different levels $\mathrm{I}(0)$ and $\mathrm{I}(1)$. Due to the fact that variables are integrated at different levels, the ARDL co-integration approach is applied to identify the long-run relationship and short-run dynamics of the variables data. The study finds that there are insignificant long-run and short-run positive relationships between FDI and export performance in Sri Lanka. The Granger causality test confirms there is no causality from FDI to export. Exports are highly sensitive to GDP and real effective exchange rate in the short-run and domestic investment in the long-run. Political risks and macroeconomic instability prevailing in Sri Lanka would hinder the chances of attracting vertically integrated assembly industries, which can have a significant impact on export performance.

In order to promote exports via FDI, the government policy should focus on attracting more FDI that could be channeled into those sectors that would contribute to national competitiveness. Due to the paucity of industry-level data, this study used aggregate level export and FDI data. The study suggests that a more comprehensive study on the impact of FDI on export performance, focusing on specific sectors, should be undertaken.

\section{References}

Ahmed, A. D., Cheng, E., \& Messinis, G. (2011). The role of exports, FDI, and imports in development: evidence from Sub-Saharan African countries. Applied Economics, 43(26), 3719-3731. http://doi.org/10.1080/00036841003705303

Akoto, W. (2016). On the Nature of the Causal Relationships Between Foreign Direct Investment, GDP, and Exports in South Africa. Journal of International Development, 28, 112-126. https://doi.org/10.1002/jid.2892

Amighini, A., \& Sanfilippo, M. (2014). Impact of South-South FDI and Trade on the Export Upgrading of African Economies. World Development, 64, 1-17.

http://doi.org/10.1016/j.worlddev.2014.05.021

Athukorala, P., \& Jayasuriya, S. (2004). Complementarity of Trade and FDI Liberalization in Industrial Growth: Lessons from Sri Lanka. In Paper presented at the International Conference of 10 Years of ASARC, Common Room, University House, ANU, Canberra, Australia, 27 \& 28 April 2004.

Balasubramanyam, V. N., Salisu, M., \& David, S. (1996). Foreign Direct Investment and Growth in EP and IS Countries. The Economic Journal, 106, 92-105.

http://doi.org/10.2307/2234933 
Bashir, F., Mujahid, M., \& Nasim, I. (2015). Exports-Led Growth Hypothesis: The Econometric Evidence From Pakistan. Canadian Social Science, 11(7), 86-95. http://doi.org/10.3968/7270

Belloumi, M. (2014). The relationship between trade, FDI and economic growth in Tunisia: An application of the autoregressive distributed lag model. Economic Systems, 38(2), 269-287. http://doi.org/10.1016/j.ecosys.2013.09.002

CBSL. (2016). 2016 Annual Report, Central Bank of Sri Lanka, Colombo, Sri Lanka.

Clus-Rossouw, D. le, Viviers, W., \& Loots, E. (2015). Is there a link between BRIC foreign direct investment and SADC export performance? Development Southern Africa, 32(6), 658-674. http://doi.org/10.1080/0376835X.2015.1063985

Davaakhuu, O., Sharma, K., \& Oczkowski, E. (2015). Has foreign investment played a role in Mongolia's export success ? Post-Communist Economies, 27(2), 256-267.

http://doi.org/10.1080/14631377.2015.1026707

Engle, R. F., \& Granger, C. W. J. (1987). Co-integration and error correction: representation, estimation, and testing. Econometrica, 55, 251-276. https://doi.org/10.2307/1913236

Gabrielle, A. (2006). Exports of Services and Economic Growth for Developing Countries. Journal of Integration, 21(2), 294-317.

Guru-Gharana, K. K., \& Adhikari, D. R. (2011). Econometric Investigation of Relationships Among Export, FDI and Growth in China: An Application of TodaYamamoto-Dolado-Lutkephol Granger Causality Test. Journal of International Business Research, 10(2), 31-51.

Haddad, M., \& Harrison, A. (1993). Are there positive spillovers from direct foreign investment?. Evidence from panel data for Morocco. Journal of Development Economics, 42(1), 51-74. http://doi.org/10.1016/0304-3878(93)90072-U

Haruna Danja, K. (2012). Foreign Direct Investment and the Nigerian Economy. American Journal of Economics, 2(3), 33-40. http://doi.org/10.5923/j.economics.20120203.02

Herrerias, M. J., \& Orts, V. (2010). Is the Export-Led Growth Hypothesis Enough to Account for China's Growth? China and World Economy, 18(4), 34-51.

http://doi.org/doi:10.1111/j.1749-124X.2010.01203.x.

Iamsiraroj, S., \& Ulubaşoğlu, M. A. (2015). Foreign direct investment and economic growth: A real relationship or wishful thinking? Economic Modelling, 51, 200-213.

http://doi.org/10.1016/j.econmod.2015.08.009

Johansen, S., \& Juselius, K. (1990). Maximum likelihood estimation and inference on co-integration with an application for the demand for money. Oxford Bulletin of Economics and Statistics, 52, 169-210. https://doi.org/10.1111/j.1468-0084.1990.mp52002003.x

Jongwanich, J. (2010). Determinants of export performance in East and Southeast Asia. The World Economy, 33(1), 20-41. https://doi.org/10.1111/j.1467-9701.2009.01184.x 
Karsalari, A. R., Mehrara, M., \& Musai, M. (2013). Export and FDI in Asian Countries: Panel Causality Analysis. Hyperion Economic Journal, 2(1), 60-66.

Kojima, K. (1975). International Trade and Foreign Investment: Substitutes or Complements. Hitotsubashi Journal of Economics, 16(1), 1-12. http://doi.org/http//doi.org/10.15057/7991

Kutan, A. M., \& Vuksic, G. (2007). Foreign Direct Investment and Export Performance: Empirical Evidence. Comparative Economic Studies, 49, 430-445.

https://doi.org/10.1057/palgrave.ces.8100216

Maneschiold, P. O. (2008). A Note on the Export-Led Growth Hypothesis: A Time Series Approach. Cuadernos de Economia, 45, 293-302.

Markusen, J. A., \& Venables, A. J. (1989). Multinational firms and the new trade theory. Journal of International Economics, 46, 183-203.

https://doi.org/10.1016/S0022-1996(97)00052-4

Mijiyawa, A. G. (2017). Does Foreign Direct Investment Promote Exports? Evidence from African Countries. The World Economy, 1934-1957. http://doi.org/10.1111/twec.12465

Mundell, A. R. (1957). International Trade and Factor Mobility. The American Economic Review, 47(3), 321-335.

Pesaran, M. H., Shin, Y., \& Smith, R. J. (2001). Bounds testing approaches to the analysis of level relationships. Journal of Applied Econometrics, 16(3), 289-326.

http://doi.org/10.1002/jae.616

Pfaffermayr, M. (1994). Foreign direct investment and exports: A time series approach. Applied Economics, 26(4), 337-351. http://doi.org/10.1080/00036849400000080

Purvis, D. D. (1972). Technology, Trade and, Factor Mobility. Economic Journal, 82(327), 991-999. https://doi.org/10.2307/2230263

Rahmaddi, R., \& Ichihashi, M. (2013). The role of foreign direct investment in Indonesia's manufacturing exports. Bulletin of Indonesian Economic Studies, 49(3), 329-354.

http://doi.org/10.1080/00074918.2013.850632

Rose, A. K. (1990). Exchange rates and the trade balance: some evidence from developing countries. Economics Letters, 34(3), 271-275. https://doi.org/10.1016/0165-1765(90)90130-S

Samuelson, P. A. (1953). Prices of Factors and Goods in General Equilibrium. The Review of Economic Studies, 21(1), 1-20. https://doi.org/10.2307/2296256

Shamim, M. A., Ghais, K. A., \& Shaikh, E. A. (2016). FDI-Export Nexus in Pakistan: A Time Series Analysis. Global Management Journal for Academic \& Corporate Studies, 6(1), 115-123.

Sun, H. (2001). Foreign direct investment and regional export performance in China. Journal of Regional Science, 41(2), 317-336. https://doi.org/10.1111/0022-4146.00219

Tabassum, U., Nazeer, M., \& Siddiqui, A. A. (2012). Impact of FDI on Import Demand and 


\section{IIMacrothink}

Business and Economic Research

ISSN 2162-4860

2018, Vol. 8, No. 3

Export Supply Functions of Pakistan : An Econometric Approach. Journal of Basic \& Applied Sciences, 8, 151-159.

Temiz, D., \& Gökmen, A. (2011). Foreign Direct Investment ( FDI ) and Export Relation in Turkey : 1991 - 2010. Journal of Transnational Management, 16(3), 157-180.

http://doi.org/10.1080/15475778.2011.596779

Tsen, W. H. (2010). Exports, Domestic Demand and Economic Growth in China: Granger Causality Analysis. Review of Development Economics, 14(3), 625-639.

https://doi.org/10.1111/j.1467-9361.2010.00578.x

UNCTAD. (2017). World Investment Report 2017 - Investment and Digital Economy. United Nations Conference on Trade and Development, Room.

Zestos, G. K., \& Tao, X. (2002). Trade and Growth: Causal Relations in the United States and Canada. Southern Economic Journal, 68(4), 859-874. https://doi.org/10.2307/1061496

Zhang, K. H. (2005). How does FDI affect a host country's export performance? The case of China. In Paper presented at the International Conference of WTO, China, and the Asian Economies III, Xi'an, China, 25-26 June.

Zhang, K. H., \& Markusen, J. R. (1999). Vertical Multinationals and Host Country Characteristics. Journal of Development Economics, 59(2), 233-252.

https://doi.org/10.1016/S0304-3878(99)00011-5

Zhang, K. H., \& Song, S. (2001). Promoting exports, the role of inward FDI in China. China Economic Review, 11(4), 385-396. https://doi.org/10.1016/S1043-951X(01)00033-5

Zilinske, A. (2010). Negative and Postive Effects of Foreign Direct Investment. Economics and Management, 15, 332-336.

\section{Copyright Disclaimer}

Copyright for this article is retained by the author(s), with first publication rights granted to the journal.

This is an open-access article distributed under the terms and conditions of the Creative Commons Attribution license (http://creativecommons.org/licenses/by/3.0/). 